Article

\title{
Chemical Composition and Evaluation of the Biological Properties of the Essential Oil of the Dietary Phytochemical Lippia citriodora
}

\author{
Eleni Fitsiou ${ }^{1}$, Gregoria Mitropoulou ${ }^{1}$, Katerina Spyridopoulou ${ }^{1}$, Manolis Vamvakias ${ }^{2}$, \\ Haido Bardouki ${ }^{2}$, Alex Galanis ${ }^{1}$, Katerina Chlichlia ${ }^{1}$ (D), Yiannis Kourkoutas ${ }^{1}$, \\ Mihalis I. Panayiotidis ${ }^{3, *}$ and Aglaia Pappa ${ }^{1, *}$ \\ 1 Department of Molecular Biology and Genetics, Democritus University of Thrace, University Campus, \\ Dragana, 68100 Alexandroupolis, Greece; elenfits@gmail.com (E.F.); grigoriamitropoulou@gmail.com (G.M.); \\ aikspiridopoulou@gmail.com (K.S.); agalanis@mbg.duth.gr (A.G.); achlichl@mbg.duth.gr (K.C.); \\ ikourkou@mbg.duth.gr (Y.K.) \\ 2 VIORYL S.A., Chemical \& Agricultural Industry, Research S.A., 19014 Afidnes, Greece; \\ vamvakias@vioryl.gr (M.V.); bardouki@vioryl.gr (H.B.) \\ 3 Department of Applied Sciences, Northumbria University, Newcastle Upon Tyne NE1 8ST, UK \\ * Correspondence: m.panagiotidis@northumbria.ac.uk (M.I.P.); apappa@mbg.duth.gr (A.P.); \\ Tel.: +44(0)-191-227-45003 (M.I.P.); +30-25510-30625 (A.P.); Fax: +30-25510-30625 (A.P.)
}

Received: 8 November 2017; Accepted: 7 January 2018; Published: 12 January 2018

\begin{abstract}
The aim of the study was to characterize the chemical composition and biological properties of the essential oil from the plant Lippia citriodora grown in Greece. The essential oil volatiles were analyzed by gas chromatography-mass spectrometry GC-MS indicating citral as the major component. The antimicrobial properties were assayed using the disk diffusion method and the minimum inhibitory and non-inhibitory concentration values were determined. Listeria monocytogenes, Staphylococcus epidermidis, Staphylococcus aureus, Saccharomyces cerevisiae, and Aspergillus niger were sensitive to Lippia citriodora oil, but not Escherichia coli, Salmonella Enteritidis, Salmonella typhimurium, and Pseudomonas fragi. Adversely, all microbes tested were sensitive to citral. 2,2-Diphenyl-1-picrylhydrazyl (DPPH) and 2,2'-azino-bis(3-ethylbenzothiazoline-6-sulphonic acid) (ABTS) assays were used to assess direct antioxidant activity, which proved to be weak for both agents, while comet assay was utilized to study the cytoprotective effects against $\mathrm{H}_{2} \mathrm{O}_{2}$-induced oxidative damage in Jurkat cells. Interestingly, the oil showed a more profound cytoprotective effect compared to citral. The antiproliferative activity was evaluated in a panel of cancer cell lines using the sulforhodamine B (SRB) and 2,3-bis(2-methoxy-4-nitro-5-sulfophenyl)-S-(phenylamino) carbonyl-2-tetrazolium hydroxide (XTT) assays and both agents demonstrated potent antiproliferative activity with citral being more cytotoxic than the oil. Taken together, the essential oil of Lippia citriodora and its major component, citral, exert diverse biological properties worthy of further investigation.
\end{abstract}

Keywords: Lippia citriodora; citral; composition; antimicrobial; antioxidant; antiproliferative

\section{Introduction}

Nowadays, public interest for natural products has increased; thus research has focused on exploring their activities as therapeutic agents for a broad range of pathological conditions including various types of cancer. Phytochemicals have been shown to reduce cancer cell viability and migration and interfere with intracellular pathways by altering the expression profiles of many genes [1-3]. Based on the promising biological properties that many compounds possess and their few side-effects, dietary natural products have attained a significant interest in being used as protective and therapeutic 
agents against cancer. In addition, there is also a growing trend in discovering new compounds of natural origin as food preservatives with many of them possessing such potential [4]. Thus, there is an ever-increasing trend in identifying novel natural compounds with biological significance for their exploitation both in the pharmaceutical and food industries.

Lippia citriodora, commonly known as lemon verbena, belongs to the Lippia genus, which contains around 200 species. It was originally cultivated in South and Central America and was brought to Europe in the 17th century [5]. There are published data on the activities of different extracts of the plant prepared by infusion or decoction [6-8]. Its leaves are mainly used for the preparation of infusions which have been utilized for the relief of gastrointestinal symptoms. In addition, antispasmodic, diuretic, and sedative properties have also been described; however, the literature is sparse regarding the biological activities of the essential oil extracted from the plant.

Therefore, the aim of this study was to identify the composition of the essential oil of Lippia citriodora isolated from Greek plants and characterize its biological activities. We report here the (i) antimicrobial; (ii) antioxidant; (iii) cytoprotective (against $\mathrm{H}_{2} \mathrm{O}_{2}$-induced oxidative damage), and (iv) antiproliferative properties associated with the essential oil fraction derived from the leaves and stems of the plant. Finally, its major component, citral, was also evaluated for its biological properties in vitro and compared to the essential oil. To our knowledge, this is the first detailed study on distinct biological properties of the essential oil fraction of Lippia citriodora.

\section{Results and Discussion}

\subsection{Chemical Composition}

A total of 43 compounds, representing $87 \%$ of the total chromatographic area, were identified (Table 1). Neral (cis-citral) and geranial (trans-citral) reported as citral (which is the sum of the two isomers) accounted for $17.2 \%$ and $26.4 \%$, respectively. Other major compounds identified were nerol (8.0\%), geraniol (5.7\%), spathulenol (3.3\%), 1.8 cineol (3.2\%) and limonene (2.2\%). The results of the present study are in accordance with existing literature as geranial is reported as one of the main components of Citriodora species essential oil [9].

Table 1. Volatiles identified in the essential oil of Lippia citriodora and their relative percent (\%) area.

\begin{tabular}{ccc}
\hline KRI $^{*}$ & Compounds & \% Area \\
\hline 795 & trans-hex-2-enal & 0.024 \\
805 & cis-hex-3-enol & 0.084 \\
819 & trans-hex-2-enol & 0.013 \\
920 & $\alpha$-pinene & 0.041 \\
946 & oct-1-en-3-one & 0.072 \\
954 & 6-methyl-hept-5-en-2-noe & 2.278 \\
956 & oct-1-en-3-ol & 1.434 \\
971 & octan-3-ol & 0.079 \\
972 & myrcene & 0.100 \\
978 & cis-hex-3-enyl acetate & 0.071 \\
1008 & 1,8-cineol & 3.150 \\
1010 & limonene & 2.166 \\
1019 & cis-b-ocimene & trace \\
1030 & trans-b-ocimene & 0.386 \\
1043 & sabinenehydrate & 0.267 \\
1077 & nonanal & 0.053 \\
1080 & linalol & 0.396 \\
1137 & cis-isocitral & 0.485 \\
1165 & $a$-terpineol & 1.119 \\
1212 & nerol & 8.047 \\
1215 & cis-citral & 17.160 \\
1219 & piperitone & 0.193 \\
\hline
\end{tabular}


Table 1. Cont.

\begin{tabular}{ccc}
\hline KRI $^{*}$ & Compounds & \% Area \\
\hline 1241 & geraniol & 5.720 \\
1246 & trans-citral & 26.404 \\
1278 & thymol or carvacrol & 0.462 \\
1324 & eugenol & 0.190 \\
1340 & geranic acid & 0.195 \\
1360 & geranyl acetate & 0.999 \\
1366 & a-copaene & 0.263 \\
1367 & methyl eugenol & 0.129 \\
1373 & b-bourbonene & 0.199 \\
1400 & a-cedrene & 0.283 \\
1405 & caryophyllene & 1.439 \\
1462 & d-germacrene & 1.150 \\
1464 & ar-curcumene & 2.098 \\
1479 & zingiberene & 0.536 \\
1479 & bicyclogermacrene & 1.750 \\
1504 & cubenol A & 0.215 \\
1543 & nerolidol & 0.753 \\
1551 & spathulenol & 3.279 \\
1554 & caryophyllene oxide & 1.375 \\
1607 & iso-spathulenol & 0.452 \\
1611 & T-cadinol & 0.558 \\
\hline
\end{tabular}

KRI*: Kovats Retention Indices.

\subsection{Antimicrobial Activitys}

The antimicrobial activity of Lippia citriodora essential oil and its main constituent was evaluated against seven common food spoilage and pathogenic bacteria, as well as against $S$. cerevisiae and A. niger, which have been used previously as model systems in food spoilage.

Initially, the disk diffusion method was applied and subsequently the minimum inhibitory concentration (MIC) and non-inhibitory concentration (NIC) values were assessed using an established optical density method, which combines the absorbance measurements with the common dilution method. Non-linear regression analysis was used to fit the data using a previously-published model $[10,11]$. The data indicated that only S. epidermidis, S. aureus, and L. monocytogenes were sensitive to Lippia citriodora essential oil, although all bacteria were sensitive to citral (Table 2). Of note, large inhibition zones were observed in both S. cerevisiae uvaferm NEM (Table 2) and A. niger 19111 for both agents (inhibition zone of $20 \pm 0.5 \mathrm{~mm}$ for 100 spores/plate initial inoculum) (the inhibition zones disappeared after one day of incubation), which were similar to the positive control [12].

Table 2. Antimicrobial activity of the Lippia citriodora essential oil against common food spoilage and pathogenic microbes monitored by the disk diffusion assay.

\begin{tabular}{ccccc}
\hline & Lippia citriodora Essential Oil & \multicolumn{2}{c}{ Citral } \\
\hline & \multicolumn{4}{c}{ Initial Inoculum } \\
\hline Microbial Species & $\mathbf{5} \mathbf{l o g} \mathbf{~ c f u} / \mathbf{m L}$ & $\mathbf{7} \mathbf{l o g} \mathbf{~ c f u} / \mathbf{m L}$ & $\mathbf{5 ~} \mathbf{l o g} \mathbf{~ c f u} / \mathbf{m L}$ & $\mathbf{7 ~} \mathbf{l o g} \mathbf{~ f f u} / \mathbf{m L}$ \\
\hline Salmonella Enteritidis & 0 & 0 & $10 \pm 0.5$ & $7 \pm 0.3$ \\
Salmonella typhimurium & 0 & 0 & $10 \pm 0.3$ & $8 \pm 0.5$ \\
Escherichia coli & 0 & 0 & $11 \pm 0.7$ & $7 \pm 0.5$ \\
Listeria monocytogenes & $12 \pm 0.7$ & $10 \pm 0.3$ & $20 \pm 0.3$ & $15 \pm 0.5$ \\
Staphylococcus epidermidis & $20 \pm 0.25$ & $16 \pm 0.3$ & $25 \pm 0.5$ & $19 \pm 0.3$ \\
Staphylococcus aureus & $13 \pm 0.5$ & $11 \pm 0.7$ & $23 \pm 0.5$ & $19 \pm 0.3$ \\
Pseudomonas fragi & 0 & 0 & $10 \pm 0.5$ & $7 \pm 0.3$ \\
Saccharomyces cerevisiae & $20 \pm 0.5$ & $12 \pm 0.7$ & $25 \pm 0.7$ & $18 \pm 0.3$ \\
\hline
\end{tabular}

The inhibition zones were measured in $\mathrm{mm}$. 
In accordance with the results of the disc diffusion method, MIC and NIC determination documented the effective growth inhibition of Lippia citriodora essential oil against S. epidermidis, S. aureus, and L. monocytogenes and citral against all bacteria tested (Table 3), although MIC and NIC values were significantly $(p<0.05)$ higher compared to ciproxin, which was used as positive control [12]. Noticeably, the oil was more effective compared to citral, as significantly $(p<0.05)$ lower MIC and NIC values were recorded. Similar results reporting high antimicrobial activity of Lippia citriodora essential oil and extracts were previously reported $[6,13,14]$. However, they were only limited to disc or well diffusion assays and no MIC and NIC values were determined. The antimicrobial activity of the essential oil could be attributed to the action of its main constituent, although possible antagonistic effects should not be excluded $[15,16]$. Such effects must be further studied using model systems.

Table 3. MIC and NIC $(\mu \mathrm{g} / \mathrm{mL})$ of Lippia citriodora essential oil and citral against common food spoilage and pathogenic bacteria. Ciproxin was used as control.

\begin{tabular}{ccccccc}
\hline & \multicolumn{2}{c}{$\begin{array}{c}\text { Lippia Citriodora } \\
\text { Essential Oil }\end{array}$} & \multicolumn{2}{c}{ Citral $^{*}$} & \multicolumn{2}{c}{$\begin{array}{c}\text { Ciproxin (Data Reproduced } \\
\text { by Fitsiou et al. [12]) }\end{array}$} \\
\hline Microbial species & MIC & NIC & MIC & NIC & MIC & NIC \\
\hline Salmonella Enteritidis & - & - & $7051 \pm 26$ & $6393 \pm 18$ & $0.976 \pm 0.001$ & $0.957 \pm 0.001$ \\
Salmonella typhimurium & - & - & $7603 \pm 26$ & $6121 \pm 9$ & $0.979 \pm 0.001$ & $0.964 \pm 0.001$ \\
Escherichia coli & - & - & $7024 \pm 9$ & $6340 \pm 18$ & $0.984 \pm 0.001$ & $0.956 \pm 0.002$ \\
Listeria monocytogenes & $1794 \pm 9$ & $179 \pm 9$ & $6919 \pm 18$ & $4981 \pm 18$ & $0.979 \pm 0.001$ & $0.968 \pm 0.001$ \\
Staphylococcus epidermidis & $1758 \pm 11$ & $538 \pm 19$ & $6954 \pm 18$ & $5779 \pm 9$ & $0.979 \pm 0.002$ & $0.957 \pm 0.002$ \\
Staphylococcus aureus & $923 \pm 19$ & $98 \pm 9$ & $6901 \pm 18$ & $4972 \pm 9$ & $0.982 \pm 0.002$ & $0.963 \pm 0.003$ \\
Pseudomonas fragi & - & - & $7112 \pm 27$ & $5235 \pm 9$ & $0.955 \pm 0.001$ & $0.940 \pm 0.002$ \\
\hline
\end{tabular}

${ }^{*}$ Mixture of $40 \%$ cis- and 60\% trans-citral.

\subsection{Antioxidant Activity}

In the present study, the DPPH and ABTS assays were used for the evaluation of the antioxidant capacity of the oil and citral. More particularly, increasing concentrations of the essential oil (0.0046-46 mg/mL) and citral $(0.0045-45 \mathrm{mg} / \mathrm{mL})$ were incubated with DPPH and ABTS for 30 and $15 \mathrm{~min}$, respectively. The $\mathrm{IC}_{50}$ values for the essential oil were $6.3 \pm 0.25 \mathrm{mg} / \mathrm{mL}$ for the DPPH assay and $3.08 \pm 0.3 \mathrm{mg} / \mathrm{mL}$ using the ABTS method. Citral did not show any significant antioxidant activity (maximum DPPH inhibition 3.9\% and ABTS inhibition 22.45\%; Table 4).

Table 4. Antioxidant activity of the essential oil of Lippia citriodora and citral using the DPPH and ABTS assays.

\begin{tabular}{cccc}
\hline & DPPH & \multicolumn{2}{c}{ ABTS } \\
\hline & IC $_{\mathbf{5 0}}(\mathbf{m g} / \mathbf{m L})$ & IC $_{\mathbf{5 0}}(\mathbf{m g} / \mathbf{m L})$ & $(\boldsymbol{\mu m o l e s E A} / \mathbf{g})$ \\
\hline Lippia citriodora oil & $6.3 \pm 0.25$ & $3.08 \pm 0.3$ & 3115.2 \\
Citral & n.d. & n.d. & 773.7 \\
Ascorbic acid & $0.0054 \pm 0.00035$ & $0.0054 \pm 0.00041$ & -
\end{tabular}

Data are presented as Mean \pm SD of at least three independent experiments, ${ }^{*}$ micromoles ascorbic acid equivalent per gram of essential oil. Ascorbic acid was used as a positive control. n.d. = not determined.

The radical scavenging activity of citral has been tested before using the DPPH and ABTS assays, showing significant activity ( $\mathrm{IC}_{50}$ values ranging from 30 to $260 \mu \mathrm{g} / \mathrm{mL}$ ), in disagreement with our results [17-19]. Compared to lemon verbena oil, its activity was weaker showing that the oil probably owes its radical scavenging activity to its other constituents, as this is the case for other oils as well [20]. Both assays showed the same trend, however, in the ABTS method, both agents demonstrated a more potent antioxidant potential. Regardless of the assays used, their activity was shown to be less when compared to the potent antioxidant, ascorbic acid (Table 4). Differences in the results from the two assays have been reported before, where extracts were found to be more effective as ABTS rather than DPPH scavengers [21,22]. These differences can be attributed to a variety of factors, such as 
stereoselectivity of the radicals, solubility of the extracts in the different systems, and underlying mechanism(s) of action of the reaction [23,24].

\subsection{Genotoxic or Cytoprotective (Against $\mathrm{H}_{2} \mathrm{O}_{2}$-Induced Oxidative Damage) Activity}

The genotoxic effects of the oil fraction or citral were investigated using the comet assay. We observed that the oil fraction demonstrated a genotoxic effect only at the highest concentration used $(920 \mu \mathrm{g} / \mathrm{mL})$ in Jurkat cells after $20 \mathrm{~min}$ of incubation, which was approximately one and a half times the levels of DNA damage of the control sample (Figure 1A). Conversely, citral exhibited a non-concentration dependent genotoxicity that reached the levels of the maximum oil-induced DNA damage at a very low concentration $(44.8 \mu \mathrm{g} / \mathrm{mL}$ ) (Figure 1B). In addition, it caused a 2.2-fold DNA damage compared to the control group at the highest concentration used $(448 \mu \mathrm{g} / \mathrm{mL})$, which was half the maximum concentration of the oil $(920 \mu \mathrm{g} / \mathrm{mL})$.

A

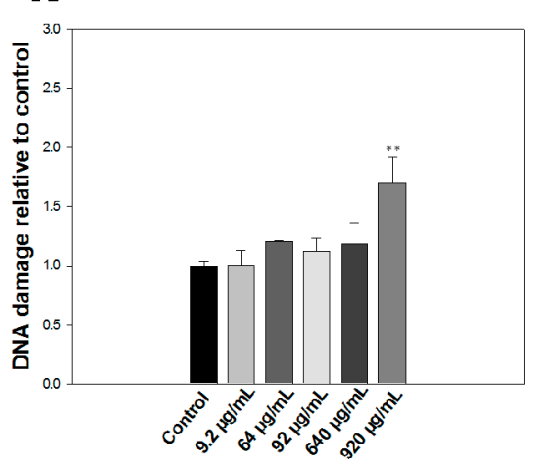

B

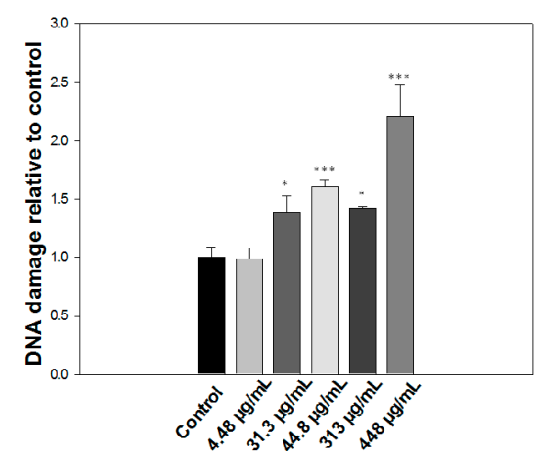

Figure 1. Detection of DNA damage caused by Lippia citriodora oil and citral in Jurkat cells using comet assay. Jurkat cells $\left(2 \times 10^{4}\right)$ were incubated with Lippia citriodora oil (A) or citral (B) for $20 \mathrm{~min}$ at room temperature. Results are shown as Mean \pm S.D. ${ }^{*} p<0.05,{ }^{* *} p<0.01,{ }^{* * *} p<0.001$.

Moreover, we used two concentrations of both agents (essential oil, 92 and $640 \mu \mathrm{g} / \mathrm{mL}$; citral, 4.48 and $44.8 \mu \mathrm{g} / \mathrm{mL}$ ) to assess the protective effect of each agent against $\mathrm{H}_{2} \mathrm{O}_{2}$-induced oxidative damage. Overall, both agents exhibited similar levels of protection only at the highest concentration used, with the oil providing slightly more protection than citral (2.24-fold vs. 2.7-fold the DNA of control sample, respectively) (Figure 2A,B).
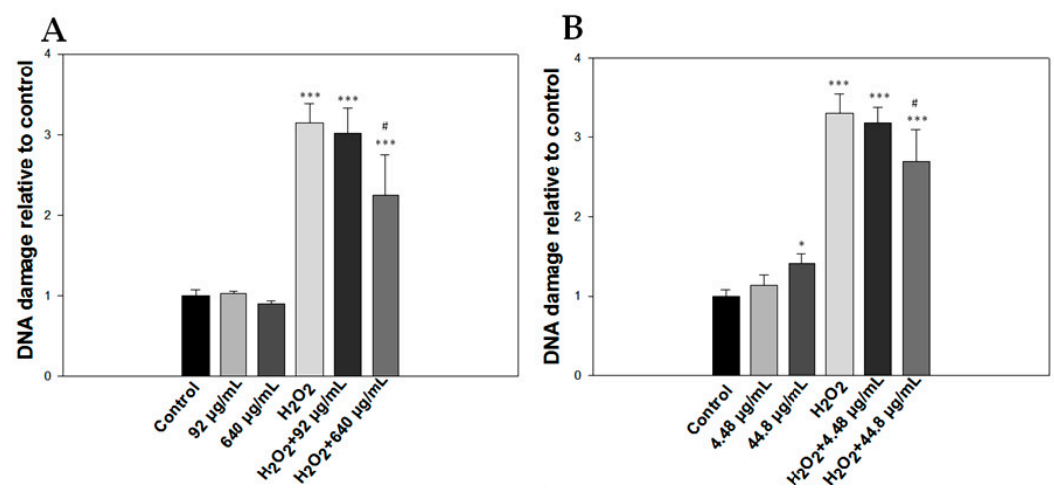

Figure 2. Detection of the protective effect of Lippia citriodora oil and citral on $\mathrm{H}_{2} \mathrm{O}_{2}$-treated Jurkat cells. Jurkat cells $\left(2 \times 10^{4}\right)$ were preincubated with Lippia citriodora oil (A) or citral (B) for 20 min before treatment with $\mathrm{H}_{2} \mathrm{O}_{2}(6.66 \mu \mathrm{g} / \mathrm{mL})$ for $20 \mathrm{~min}$ at room temperature. Results are shown as mean \pm S.D. ${ }^{\#} p=0.013 \mathrm{H}_{2} \mathrm{O}_{2}$ vs. $\mathrm{H}_{2} \mathrm{O}_{2}$ and $640 \mu \mathrm{g} / \mathrm{mL}$ essential oil, ${ }^{\#} p<0.05$ relative to $\mathrm{H}_{2} \mathrm{O}_{2},{ }^{* * *} p<0.001$ relative to control. 
The oil from Lippia citriodora together with citral have been previously evaluated for their antigenotoxic effect against ultraviolet radiation-induced DNA damage using the SOS chromosome test, where they both showed antigenotoxicity [25]. Citral has shown diverse toxicity using different test systems. For instance, it not did exhibit direct pro-oxidant effect when testing oxygen uptake in erythrocytes exposed to tert-butyl hydroperoxide (t-BHP) [26], nor did it reduce the viability of rat small intestine epithelial cells after $24 \mathrm{~h}$ of incubation [17]. When using the Salmonella mutagenicity testing, Gomes-Carneiro et al., demonstrated that citral was toxic at concentrations higher than $600 \mu \mathrm{g} / \mathrm{mL}$, whereas it did not demonstrate any such genotoxicity when utilizing the SOS chromotest [27,28]. Moreover, in a similar study, citral was shown to reduce the viability of human lymphocytes over $100 \mu \mathrm{g} / \mathrm{mL}$ using the MTT assay and cause statistically significant DNA damage at even lower concentrations $(>25 \mu \mathrm{g} / \mathrm{mL})$, in accordance with our results [29].

\subsection{Antiproliferative Activity}

Increasing concentrations of the essential oil fraction $(0.64-920 \mu \mathrm{g} / \mathrm{mL})$ or citral $(0.63-900 \mu \mathrm{g} / \mathrm{mL})$ were incubated with different human cancer cell lines (for $72 \mathrm{~h}$ ) and SRB or XTT assays were employed to determine cell viability. Overall, it was observed that the oil fraction was most cytotoxic against the $\mathrm{A} 375$ (melanoma) cells $\left(\mathrm{EC}_{50}=9.1 \pm 0.6 \mu \mathrm{g} / \mathrm{mL}\right)$, an activity eight to ten times higher compared to the other cell lines tested. In addition, it showed similar viability levels against HepG2 (hepatocellular carcinoma), MCF-7 (breast adenocarcinoma) and Caco2 (colon adenocarcinoma) cells $\left(\mathrm{EC}_{50}=74 \pm 2.8 \mu \mathrm{g} / \mathrm{mL}, 89 \pm 1.4 \mu \mathrm{g} / \mathrm{mL}\right.$ and $71 \pm 2.6 \mathrm{mg} / \mathrm{mL}$, respectively $)$, while it was slightly less cytotoxic against THP-1 (leukemic monocytes) cells $\left(\mathrm{EC}_{50}=111 \pm 3.6 \mu \mathrm{g} / \mathrm{mL}\right)$ (Figure 3 and Table 5). Finally, the oil fraction demonstrated modest cytotoxicity to the lines tested compared with etoposide, a known chemotherapeutic agent. To our knowledge, there are no published data on the cytotoxicity of the essential oil of Lippia citriodora against HepG2 and Caco2 cell lines. In a study in 2010, Escobar et al. showed the effect of Lippia citriodora oil (from Colombian plants) against Vero and THP-1 cells where the $\mathrm{EC}_{50}$ value for THP-1 was $>100 \mu \mathrm{g} / \mathrm{mL}$, in accordance with our results [30]. There is also one study describing the cytotoxic activity of Aloysia citriodora oils from different regions of Morocco against MCF-7 cells after a $48 \mathrm{~h}$ incubation, where the $\mathrm{EC}_{50}$ values ranged between 35 and $70 \mu \mathrm{g} / \mathrm{mL}$, whereas there was no cytotoxicity observed against PBMCs [31]. In this case, the oils demonstrated higher activity compared to our oil, which may be attributed to the differences in their composition, as the Moroccan oils had $\beta$-spathulenol, trans-caryophyllene oxide and ar-curcumene as major components.

On the other hand, citral was significantly more potent against all cell lines tested, an observation which could owe to an antagonistic effect between the components of the essential oil. In general, MCF-7 cells were the most sensitive ones when subjected to citral $\left(\mathrm{EC}_{50}=1.3 \pm 0.19 \mu \mathrm{g} / \mathrm{mL}\right)$, followed by Caco2 and HepG2 cells $\left(\mathrm{EC}_{50}=3.7 \pm 0.21 \mu \mathrm{g} / \mathrm{mL}\right.$ and $7 \pm 0.35 \mu \mathrm{g} / \mathrm{mL}$, respectively) (Figure 4 and Table 5). To this end, another study utilizing citral (obtained commercially) and also tested against MCF-7 cells showed an $\mathrm{EC}_{50}$ value of $22 \mu \mathrm{g} / \mathrm{mL}$ [32], an effect significantly smaller than that of our study, which may be attributed to the different cell viability assay used. In another study, citral has been tested against HepG2 cells after 24 and $48 \mathrm{~h}$ of incubation $\left(\mathrm{EC}_{50}=30.129\right.$ and $14.67 \mu \mathrm{g} / \mathrm{mL}$, respectively), in accordance with our results, where after $72 \mathrm{~h}$ the $\mathrm{EC}_{50}$ value was even lower, suggesting a time-dependent effect [19], while it has also been tested for its cytotoxicity against a range of human cancer cell lines including breast carcinoma, glioblastoma, malignant melanoma, and colon carcinoma after a $72 \mathrm{~h}$ incubation, exhibiting potent activity [18]. 


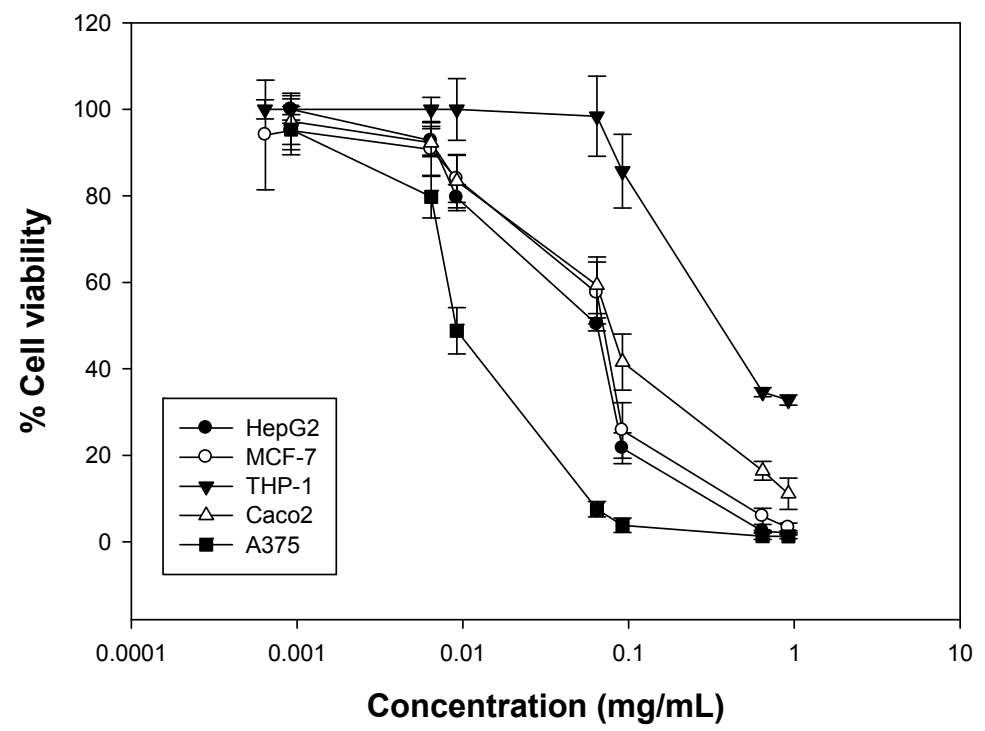

Figure 3. Antiproliferative activity of Lippia citriodora oil against a panel of five human cancer cell lines. Cancer cells were incubated with increasing concentrations of citral for $72 \mathrm{~h}$. Estimation of cell viability was determined by the SRB assay. Representative figures of at least three experiments.

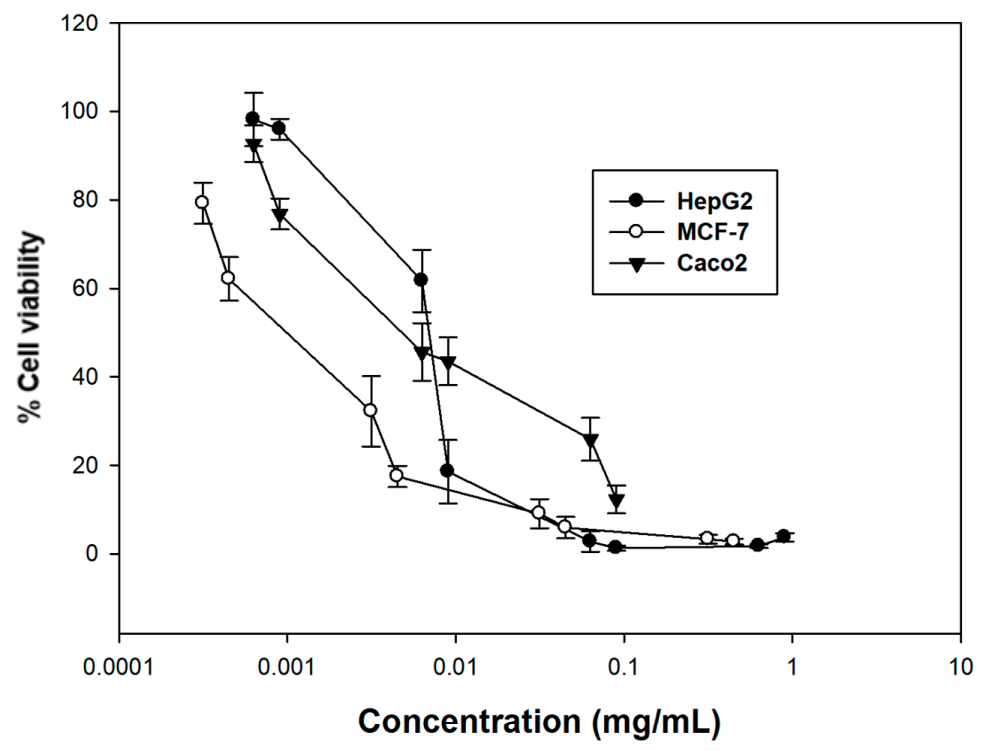

Figure 4. Antiproliferative activity of citral against a panel of three human cancer cell lines. Cancer cells were incubated with increasing concentrations of citral for $72 \mathrm{~h}$. Estimation of cell viability was determined by the SRB assay. Representative figures of at least three experiments.

Table 5. $\mathrm{EC}_{50}$ values of the essential oil of Lippia citriodora and its major component, citral, against different human cell lines. Etoposide was used as a positive control.

\begin{tabular}{cccccc}
\hline \multicolumn{7}{c}{ EC $_{\mathbf{5 0}}(\boldsymbol{\mu g} / \mathrm{mL})$} \\
\hline & HepG2 & Caco2 & MCF-7 & THP-1 & A375 \\
\hline Lippia citriodora oil & $74 \pm 2.8$ & $71 \pm 2.6$ & $89 \pm 1.4$ & $111 \pm 3.6$ & $9.1 \pm 0.6$ \\
Citral & $7 \pm 0.35$ & $3.7 \pm 0.21$ & $1.3 \pm 0.19$ & - & - \\
Etoposide & $0.60 \pm 0.06$ & $7.3 \pm 0.63$ & $1.67 \pm 0.41$ & $0.45 \pm 0.013$ & - \\
\hline
\end{tabular}

Data are presented as mean \pm SD of at least three independent experiments. 


\section{Materials and Methods}

\subsection{Plant Material}

Plant material was purchased by Vioryl S.A. from a local area herbal market (Afidnes, Athens, Greece) and the species was confirmed by a professional botanist. Plants were small shrubs of almost $60 \mathrm{~cm}$ height. They were kept in pots until the first inflorescence appeared and leaves and stems were collected.

\subsection{Chemicals and Reagents}

Brain heart infusion (BHI) broth, malt extract agar, and Ringer's solution were obtained from LABM (Heywood, UK). Ciproxin was obtained from Oxoid Ltd. (Basingstoke, UK) and amphotericin B from Mast Group Ltd. (Merseyside, UK). Dulbecco's Modified Eagle's Medium (DMEM), DMEM high glucose, RPMI media, and low melting agarose were purchased from Gibco ${ }^{\circledR}$ (Gaithersburg, MD, USA). Fetal bovine serum (FBS), trypsin, penicillin/streptomycin, trypan blue $0.5 \%$, and phosphate-buffered saline (PBS) were purchased from Biosera (Boussens, France). Dimethyl sulfoxide (DMSO) and propidium iodide were purchased from Biotium (Hayward, CA, USA), while hydrogen peroxide, ABTS, potassium persulfate, ascorbic acid, sulforhodamine B (SRB), Trizma base, and etoposide were purchased from Sigma-Aldrich (St. Louis, MO, USA). Trichloroacetic acid (TCA) was obtained from MP Biomedicals (Santa Ana, CA, USA). Acetic acid and ethanol were purchased from Scharlau (Barcelona, Spain) and DPPH from Calbiochem ${ }^{\circledR}$ (Darmstadt, Germany).

\subsection{Essential Oil Extraction and GC/MS Analysis}

The essential oil was obtained by hydrodistillation at VIORYL S.A. facilities (Afidnes, Athens, Greece) directly after the harvesting period, taking into account the seasonality of the plant. All plants were harvested during May and June, and no further drying process was used. Chopped leaves and stems were collected by hand, followed by hydrodistillation with a Dean Stark apparatus. Plant material was covered with $6 \mathrm{~L}$ of distilled water, while the extraction process took place for $8 \mathrm{~h}$ at a temperature of $90-120{ }^{\circ} \mathrm{C}$. Isolated essential oil was dried with $\mathrm{Na}_{2} \mathrm{SO}_{4}$ and sealed in vials for further use. Analysis was carried out with a GC-MS (GC: 6890A, Agilent Technologies, Santa Clara, CA, USA; MSD: 5973, Agilent Technologies, Santa Clara, CA, USA) using a Factor Four VF $1 \mathrm{~ms}$ column ( 25 m, 0.2 mm i.d., $0.33 \mu \mathrm{m}$ film thickness, Agilent Technologies, Santa Clara, CA, USA). A volume of $0.1 \mu \mathrm{L}$ of essential oil was directly injected and a 1:100 split ratio was applied. Oven temperature was set at $50{ }^{\circ} \mathrm{C}$ for $1 \mathrm{~min}$, followed by a temperature gradient of $2.5^{\circ} \mathrm{C} / \mathrm{min}$ to $160{ }^{\circ} \mathrm{C}$ (for $20 \mathrm{~min}$ ), then raised to $250{ }^{\circ} \mathrm{C}$ at $50{ }^{\circ} \mathrm{C} / \mathrm{min}$ with a final isothermal period of $15 \mathrm{~min}$. Helium was used as the carrier gas (flow rate $1 \mathrm{~mL} / \mathrm{min}$ ). Injector and transfer line temperatures were set to $200{ }^{\circ} \mathrm{C}$ and $250{ }^{\circ} \mathrm{C}$, respectively. The mass spectrometer operated in the electron impact mode with the electron energy set to $70 \mathrm{eV}$. Identification of the compounds was carried out according to the standard method of Kováts Indices and comparison of volatiles mass spectra to Willey/NIST 0.5 and in-house created libraries (VIORYL S.A.).

\subsection{Microbial Strains}

Salmonella enterica subsp. enterica ser. Enteritidis FMCC B56 PT4 (kindly provided by Prof. Nychas G.J.E., Agricultural University of Athens, Athens, Greece), Salmonella enterica subsp. enterica ser. typhimurium DSMZ 554, Listeria monocytogenes NCTC 10527 serotype 4b, Escherichia coli ATCC 25922, Staphylococcus epidermidis FMCC B-202 C5M6 (kindly provided by Dr. Nisiotou A., Athens Wine Institute, ELGO-DIMITRA, Athens, Greece) and Staphylococcus aureus ATCC 25923 were grown in BHI at $37^{\circ} \mathrm{C}$ for $24 \mathrm{~h}$. Likewise, Pseudomonas fragi 211 (kindly provided by Prof. Nychas G.J.E., Agricultural University of Athens, Greece) was grown in BHI broth at $25{ }^{\circ} \mathrm{C}$ for $24 \mathrm{~h}$. Saccharomyces cerevisiae uvaferm NEM (Lallemand, Montreal, QC, Canada) was grown in YPD broth (yeast extract, $10 \mathrm{~g} / \mathrm{L}$; glucose, $20 \mathrm{~g} / \mathrm{L}$; and peptone, $20 \mathrm{~g} / \mathrm{L}$ ) at $28{ }^{\circ} \mathrm{C}$ for three days. Aspergillus niger 19111 (kindly provided 
by Prof. Nychas G.J.E., Agricultural University of Athens) was grown on malt extract agar for seven days at $37^{\circ} \mathrm{C}$.

\subsection{Antimicrobial Assays}

The antimicrobial activity of the tested essential oil and determination of minimum inhibitory concentration (MIC) and non-inhibitory concentration (NIC) based on the Lambert-Pearson model (LPM) [10,11] were monitored using previously published methodologies [12,33]. In brief, the effect on the growth, measured by the optical density method, is manifested by a reduction in the area under the OD/time relative to a control well at any specified time (supplementary material). By calculating the area using the trapezoidal rule (Equation (1)), the relative amount of growth were obtained using the ratio of the test area to that of the control, termed the fractional area, $f a$. Data were fitted to the LPM using non-linear least squares regression analysis assuming equal variance.

$$
f a=\exp \left[-\left(\frac{x}{P_{1}}\right)^{P_{2}}\right]
$$

where $f a$ is the fractional area, $x$ is the inhibitor concentration $(\mu \mathrm{g} / \mathrm{mL}), P_{1}$ is the concentration at maximum slope (of a $\log x$ vs. $f a$ plot), and $P_{2}$ is a slope parameter.

MIC was defined as the intercept of the concentration axis to the tangent at the maximum gradient of the $f a / \log$ concentration curve (Equation (2)):

$$
M I C=P_{1} \exp \left(\frac{1}{P_{2}}\right)
$$

NIC was defined as the intercept of the tangent at the maximum gradient of the $f a / \log$ concentration curve to the $f a=1$ contour (Equation (3)):

$$
N I C=P_{1} \exp \left(\frac{1-e}{P_{2}}\right)
$$

\subsection{Antioxidant Activity}

\subsubsection{DPPH Assay}

The radical scavenging activity of the essential oil and citral was estimated using the free radical $\mathrm{DPPH}$, as previously described [12]. Increasing concentrations of the essential oil $(0.0046-46 \mathrm{mg} / \mathrm{mL})$ and citral (0.0045-45 mg/mL) were prepared using DMSO as the solvent. Absorbance was measured at $517 \mathrm{~nm}$ using an ELISA plate reader (EnSpire Multimode Plate Reader, Perkin Elmer, Waltham, MA, USA). All determinations were performed in triplicates. The $\%$ inhibition of the DPPH radical for each concentration was determined by making use of the following formula: \% DPPH radical scavenging activity $\left.=\left[\left(\mathrm{OD}_{\text {control }}-\mathrm{OD}_{\text {sample }}\right) / \mathrm{OD}_{\text {control }}\right)\right] \times 100$.

\subsubsection{ABTS Assay}

The ABTS de-coloration assay was performed as previously described $[12,34]$. The $\%$ inhibition of the ABTS radical for each concentration is expressed in two ways; First, by making use of the following formula: \% ABTS radical scavenging activity $\left.=\left[\left(\mathrm{OD}_{\text {control }}-\mathrm{OD}_{\text {sample }}\right) / \mathrm{OD}_{\text {control }}\right)\right] \times 100$. Next, a standard curve based on the percentage of ABTS radical scavenging activity of known concentrations of ascorbic acid expressed in $\mu \mathrm{M}$ was prepared and the concentrations of the samples were calculated using linear regression analysis and the results were also expressed as micromoles ascorbic acid equivalent per gram of essential oil ( $\mu$ molesEA/g), by making use of the following formula: $\mathrm{C}=(\mathrm{cxD}) / \mathrm{Ci}$. $\mathrm{C}$, concentration of antioxidant compounds in $\mu$ molesEA/g; $c$, concentration 
of sample read (in micromoles per liter); $\mathrm{D}$, dilution factor; $\mathrm{Ci}$, concentration of stock solution (in grams per liter).

\subsection{Cell Lines and Cell Cultures}

The human cancer cell lines Caco2 (colorectal adenocarcinoma), HepG2 (hepatocellular carcinoma), MCF-7 (breast adenocarcinoma), THP-1 (leukemic monocytes), Jurkat (acute T cell leukemia), and A375 (malignant melanoma) were obtained from the American type culture collection (Rockville, MD, USA). HepG2 and MCF-7 cells were grown and maintained in DMEM, A375 cells in DMEM high glucose $(4500 \mathrm{mg} / \mathrm{L})$, whereas the medium RMPI was used for the Caco2, Jurkat, and THP-1 cell lines. All media were supplemented with $10 \%$ FBS, penicillin $(100 \mathrm{U} / \mathrm{mL})$, and streptomycin $(100 \mu \mathrm{g} / \mathrm{mL})$ and were incubated at $37{ }^{\circ} \mathrm{C}$ in a humidified atmosphere of $95 \% \mathrm{O}_{2}$ and $5 \% \mathrm{CO}_{2}$. Stock cultures were passaged at 2- to 3-day intervals. Cells were seeded at a density of $5.0 \times 10^{3}$ cells per well in 96-well plates for the SRB assay. THP- 1 cells were seeded at a density of $2.0 \times 10^{3}$ cells per well in round bottom 96-well plates for the XTT assay.

\subsection{Single Cell Gel Electrophoresis Assay (Comet Assay)}

The alkaline version of the single-cell gel electrophoresis assay was used to evaluate DNA damage of the essential oil and citral, as well as their protective effect from $\mathrm{H}_{2} \mathrm{O}_{2}$-induced oxidative damage. Briefly, Jurkat cells $\left(2 \times 10^{4}\right.$ cells/sample in PBS) were maintained on ice. Cells were treated with increasing concentrations of the essential oil or citral alone for $20 \mathrm{~min}$ or followed by treatment with $\mathrm{H}_{2} \mathrm{O}_{2}(6.66 \mu \mathrm{g} / \mathrm{mL})$ for another $20 \mathrm{~min}$ at room temperature. Comet assay was performed as previously described [35]. The slides were processed for evaluation on a Zeiss Axio Scope.A1 fluorescence microscope (Oberkochen, Germany). The overall DNA damage was calculated in arbitrary units. Results were expressed as \% DNA damage relative to control.

\subsection{Cell Viability Assays}

\subsubsection{SRB Assay}

The viability of the human cancer cells HepG2, Caco2, MCF-7, and A375 after treatment with the essential oil and its major component was determined using the SRB assay as previously described [12]. Cells were plated in 96-well plates and treated with increasing concentrations of the oil $(0.64-920 \mu \mathrm{g} / \mathrm{mL})$ and citral $(0.63-900 \mu \mathrm{g} / \mathrm{mL}$ ) (dissolved in DMSO, 1:1 v/v) for $72 \mathrm{~h}$.

\subsubsection{XTT Assay}

The viability of THP-1 cells was determined by the XTT assay as previously described $[12,36]$. Cells were seeded in a 96-well-plate and following an overnight incubation they were treated with increasing concentrations of the oil $(0.64-920 \mu \mathrm{g} / \mathrm{mL})$ or citral $(0.63-900 \mu \mathrm{g} / \mathrm{mL})$ (dissolved in DMSO, $1: 1 v / v)$ for $72 \mathrm{~h}$. At the end of the incubation, the XTT solution was added, and plates were incubated further for $4 \mathrm{~h}$ before reading the absorbance at $450 \mathrm{~nm}$ by a microplate reader (EnSpire Multimode Plate Reader, Perkin Elmer, Waltham, MA, USA).

\subsection{Data Analysis}

All experiments were performed at least in triplicate. For MIC and NIC determination, each experiment was performed at least 4 times, and standard deviation was calculated by Fig.P software (Fig.P Software Incorporated, Hamilton, ON, Canada). Significance was established at $p<0.05$ and the results were analyzed for statistical significance with analysis of variance (ANOVA). Duncan's multiple range test was used to determine significant differences among results using Statistica v.10.0. The $\mathrm{IC}_{50}$ (inhibition concentration) and $\mathrm{EC}_{50}$ (efficient concentration) values were calculated as previously described [12]. For comet assay, statistical differences between groups were evaluated by ANOVA followed by Dunnett's or Tukey's test. A level of $p<0.05$ was considered statistically 
significant. All statistical analyses were performed using GraphPad Prism 5 (GraphPad Software, San Diego, CA, USA).

\section{Conclusions}

Citral is the major component of the essential oil of Lippia citriodora (obtained from Greek plants) and exhibited significant antimicrobial activity against all microbes tested in contrast to the oil fraction which was inactive against the gram negative bacteria. Our results also suggest that both the oil fraction and citral exhibit potent antiproliferative activities in vitro. More specifically, citral was more cytotoxic against all cancer cell lines utilized in the scope of this study while the oil fraction exhibited lower genotoxicity. Although both the oil and citral proved weak direct antioxidants as assessed by biochemical in vitro assays, they, nevertheless, exhibited antioxidant capacity in a cellular system demonstrated as a significant reduction of the $\mathrm{H}_{2} \mathrm{O}_{2}$-induced oxidative damage. Many of these properties are reported here for the first time, thus setting the basis for further investigations regarding the active components of the oil and the molecular mechanisms(s) underlying their mode of action. This is of utmost importance as the demand in identifying natural products with well-described biological properties for potential neutraceutical and pharmaceutical applications is constantly increasing.

Supplementary Materials: Supplementary materials are available online.

Acknowledgments: We acknowledge support of this work by the project "OPENSCREEN-GR: An Open-Access Research Infrastructure of Target-Based Screening Technologies and Chemical Biology for Human and Animal Health, Agriculture and Environment" (MIS 5002691) which is implemented under the Action "Reinforcement of the Research and Innovation Infrastructure", funded by the Operational Programme "Competitiveness, Entrepreneurship and Innovation" (NSRF 2014-2020) and co-financed by Greece and the European Union (European Regional 326 Development Fund). Start-up funds provided by the MDRT "Bioeconomy" at Northumbria University-Newcastle, UK to M.I.P. are kindly acknowledged. The authors thank C. Tassou for providing full access to microplate reader equipment, N. Chorianopoulos for his valuable technical support and scientific advice, and greatly acknowledge the assistance of Eleni Papavasilopoulou and Dimitris Georganakis from VIORYL S.A.

Author Contributions: H.B., M.I.P., A.G., K.C., Y.K. and A.P. conceived and designed the experiments; E.F., G.M., K.S., M.V. and H.B. performed the experiments; E.F., G.M. and K.S. analyzed the data; and E.F., Y.K. and A.P. wrote the paper.

Conflicts of Interest: The authors declare no conflict of interest.

\section{References}

1. González-Vallinas, M.; González-Castejón, M.; Rodríguez-Casado, A.; Ramírez de Molina, A. Dietary phytochemicals in cancer prevention and therapy: A complementary approach with promising perspectives. Nutr. Rev. 2013, 71, 585-599. [CrossRef] [PubMed]

2. Miller, P.E.; Snyder, D.C. Phytochemicals and cancer risk: A review of the epidemiological evidence. Nutr. Clin. Pract. 2012, 27, 599-612. [CrossRef] [PubMed]

3. Stagos, D.; Amoutzias, G.D.; Matakos, A.; Spyrou, A.; Tsatsakis, A.M.; Kouretas, D. Chemoprevention of liver cancer by plant polyphenols. Food Chem. Toxicol. 2012, 50, 2155-2170. [CrossRef] [PubMed]

4. Tongnuanchan, P.; Benjakul, S. Essential oils: Extraction, bioactivities, and their uses for food preservation. J. Food Sci. 2014, 79, R1231-R1249. [CrossRef] [PubMed]

5. Quirantes-Piné, R.; Herranz-López, M.; Funes, L.; Borrás-Linares, I.; Micol, V.; Segura Carretero, A.; Fernández-Gutiérrez, A. Phenylpropanoids and their metabolites are the major compounds responsible for blood-cell protection against oxidative stress after administration of Lippia citriodora in rats. Phytomedicine 2013, 20, 1112-1118. [CrossRef] [PubMed]

6. Mothana, R.A.; Abdo, S.A.; Hasson, S.; Althawab, F.M.; Alaghbari, S.A.; Lindequist, U. Antimicrobial, antioxidant and cytotoxic activities and phytochemical screening of some Yemeni medicinal plants. Evid. Based Complement. Altern. Med. 2010, 7, 323-330. [CrossRef] [PubMed] 
7. Portmann, E.; Nigro, M.M.; Reides, C.G.; Llesuy, S.; Ricco, R.A.; Wagner, M.L.; Gurni, A.A.; Carballo, M.A. Aqueous extracts of Lippia turbinata and Aloysia citriodora (Verbenaceae): Assessment of antioxidant capacity and DNA damage. Int. J. Toxicol. 2012, 31, 192-202. [CrossRef] [PubMed]

8. Valentão, P.; Fernandes, E.; Carvalho, F.; Andrade, P.B.; Seabra, R.M.; de Lourdes Basto, M. Studies on the antioxidant activity of Lippia citriodora infusion: Scavenging effect on superoxide radical, hydroxyl radical and hypochlorous acid. Biol. Pharm. Bull. 2002, 25, 1324-1327. [CrossRef] [PubMed]

9. Linde, J.; Combrinck, S.; Regnier, T.; Virijevic, S. Chemical composition and antifungal activity of the essential oils of Lippia rehmannii from South Africa. S. Afr. J. Bot. 2010, 76, 37-42. [CrossRef]

10. Chorianopoulos, N.; Lambert, R.J.W.; Skandamis, P.N.; Evergetis, E.T.; Haroutounian, S.A.; Nychas, G.J.E. A newly developed assay to study the minimum inhibitory concentration of Satureja spinosa essential oil. J. Appl. Microbiol. 2006, 100, 778-786. [CrossRef] [PubMed]

11. Lambert, R.J.W.; Lambert, R. A model for the efficacy of combined inhibitors. J. Appl. Microbiol. 2003, 95, 734-743. [CrossRef] [PubMed]

12. Fitsiou, E.; Mitropoulou, G.; Spyridopoulou, K.; Tiptiri-Kourpeti, A.; Vamvakias, M.; Bardouki, H.; Panayiotidis, M.I.; Galanis, A.; Kourkoutas, Y.; Chlichlia, K.; et al. Phytochemical Profile and Evaluation of the Biological Activities of Essential Oils Derived from the Greek Aromatic Plant Species Ocimum basilicum, Mentha spicata, Pimpinella anisum and Fortunella margarita. Molecules 2016, 21, 1069. [CrossRef] [PubMed]

13. Ali, H.F.; El-Beltagi, H.S.; Nasr, N.F. Evaluation of antioxidant and antimicrobial activity of Aloysia triphylla. Electron. J. Environ. Agric. Food Chem. 2011, 10, 3044-3053.

14. Koohsari, H.; Ghaemi, E.A.; Poli, M.S.S.; Sadegh, A. Evaluation of antibacterial activity of Lemon verbena (Lippia citriodora) leaves. Ann. Biol. Res. 2013, 4, 52-55.

15. Burt, S. Essential oils: Their antibacterial properties and potential applications in foods-A review. Int. J. Food Microbiol. 2004, 94, 223-253. [CrossRef] [PubMed]

16. Nazzaro, F.; Fratianni, F.; De Martino, L.; Coppola, R.; De Feo, V. Effect of Essential Oils on Pathogenic Bacteria. Pharmaceuticals 2013, 6, 1451-1474. [CrossRef] [PubMed]

17. Bouzenna, H.; Hfaiedh, N.; Giroux-Metges, M.A.; Elfeki, A.; Talarmin, H. Biological properties of citral and its potential protective effects against cytotoxicity caused by aspirin in the IEC- 6 cells. Biomed. Pharmacother. 2017, 87, 653-660. [CrossRef] [PubMed]

18. Maggi, F.; Fortuné Randriana, R.; Rasoanaivo, P.; Nicoletti, M.; Quassinti, L.; Bramucci, M.; Lupidi, G.; Petrelli, D.; Vitali, L.A.; Papa, F.; et al. Chemical composition and in vitro biological activities of the essential oil of Vepris macrophylla (BAKER) I. Verd. endemic to Madagascar. Chem. Biodivers. 2013, 10, 356-366. [CrossRef] [PubMed]

19. Shi, C.; Zhao, X.; Liu, Z.; Meng, R.; Chen, X.; Guo, N. Antimicrobial, antioxidant, and antitumor activity of epsilon-poly-L-lysine and citral, alone or in combination. Food Nutr. Res. 2016, 60, 31891. [CrossRef] [PubMed]

20. Dawidowicz, A.L.; Olszowy, M. Does antioxidant properties of the main component of essential oil reflect its antioxidant properties? The comparison of antioxidant properties of essential oils and their main components. Nat. Prod. Res. 2014, 28, 1952-1963. [CrossRef] [PubMed]

21. Bendif, H.; Boudjeniba, M.; Miara, M.D.; Biqiku, L.; Bramucci, M.; Lupidi, G.; Quassinti, L.; Maggi, F. Essential oil of Thymus munbyanus subsp. coloratus from Algeria: Chemotypification and in vitro biological activities. Chem. Biodivers. 2016, 14. [CrossRef]

22. Osuna-Ruiz, I.; López-Saiz, C.M.; Burgos-Hernández, A.; Velázquez, C.; Nieves-Soto, M.; Hurtado-Oliva, M.A. Antioxidant, antimutagenic and antiproliferative activities in selected seaweed species from Sinaloa, Mexico. Pharm. Biol. 2016, 54, 2196-2210. [CrossRef] [PubMed]

23. Bayala, B.; Bassole, I.H.; Gnoula, C.; Nebie, R.; Yonli, A.; Morel, L.; Figueredo, G.; Nikiema, J.B.; Lobaccaro, J.M.; Simpore, J. Chemical composition, antioxidant, anti-inflammatory and antiproliferative activities of essential oils of plants from Burkina Faso. PLoS ONE 2014, 9, e92122. [CrossRef] [PubMed]

24. Yu, L.; Haley, S.; Perret, J.; Harris, M.; Wilson, J.; Qian, M. Free radical scavenging propertiesof wheat extracts. J. Agric. Food Chem. 2002, 50, 1619-1624. [CrossRef] [PubMed]

25. Quintero Ruiz, N.; Córdoba Campo, Y.; Stashenko, E.E.; Fuentes, J.L. Antigenotoxic Effect Against Ultraviolet Radiation-induced DNA Damage of the Essential Oils from Lippia Species. Photochem. Photobiol. 2017, 93, 1063-1072. [CrossRef] [PubMed] 
26. Sanches, L.J.; Marinello, P.C.; Panis, C.; Fagundes, T.R.; Morgado-Díaz, J.A.; de-Freitas Junior, J.C.; Cecchini, R.; Cecchini, A.L.; Luiz, R.C. Cytotoxicity of citral against melanoma cells: The involvement of oxidative stress generation and cell growth protein reduction. Tumour Biol. 2017, 39, 1010428317695914. [CrossRef] [PubMed]

27. Gomes-Carneiro, M.R.; Felzenszwalb, I.; Paumgartten, F.J. Mutagenicity testing (+/-)camphor, 1,8 cineole, citral, citronellal, (-)-menthol and terpineol with the Salmonella/microsome assay. Mutat. Res. 1998, 416, 129-136. [CrossRef]

28. López, M.A.; Stashenko, E.E.; Fuentes, J.L. Chemical composition and antigenotoxic properties of Lippia alba essential oils. Genet. Mol. Biol. 2011, 34, 479-488. [CrossRef] [PubMed]

29. Sinha, S.; Jothiramajayam, M.; Ghosh, M.; Mukherjee, A. Evaluation of toxicity of essential oils palmarosa, citronella, lemongrass and vetiver in human lymphocytes. Food Chem. Toxicol. 2014, 68, 71-77. [CrossRef] [PubMed]

30. Escobar, P.; Milena Leal, S.; Herrera, L.V.; Martinez, J.R. Stashenko, E. Chemical composition and antiprotozoal activities of Colombian Lippia spp essential oils and their major components. Mem. Inst. Oswaldo Cruz 2010, 105, 184-190. [CrossRef] [PubMed]

31. Oukerrou, M.A.; Tilaoui, M.; Mouse, H.A.; Leouifoudi, I.; Jaafari, A.; Zyad, A. Chemical Composition and Cytotoxic and Antibacterial Activities of the Essential Oil of Aloysia citriodora Palau Grown in Morocco. Adv. Pharmacol. Sci. 2017, 7801924. [CrossRef] [PubMed]

32. Chaouki, W.; Leger, D.Y.; Liagre, B.; Beneytout, J.L.; Hmamouchi, M. Citral inhibits cell proliferation and induces apoptosis and cell cycle arrest in MCF-7 cells. Fundam. Clin. Pharmacol. 2009, 23, 549-556. [CrossRef] [PubMed]

33. Mitropoulou, G.; Fitsiou, E.; Stavropoulou, E.; Papavassilopoulou, E.; Vamvakias, M.; Pappa, A.; Oreopoulou, A.; Kourkoutas, Y. Composition, antimicrobial, antioxidant, and antiproliferative activity of Origanum dictamnus (dittany) essential oil. Microb. Ecol. Health Dis. 2015, 6, 26543.

34. Re, R.; Pellegrini, N.; Proteggente, A.; Pannala, A.; Yang, M.; Rice-Evans, C. Antioxidant activity applying an improved ABTS radical cation decolorization assay. Free Radic. Biol. Med. 1999, 26, 1231-1237. [CrossRef]

35. Panayiotidis, M.; Tsolas, O.; Galaris, D. Glucose oxidase-produced $\mathrm{H}_{2} \mathrm{O}_{2}$ induces $\mathrm{Ca}^{2+}$ Dependent DNA damage in human peripheral blood lymphocytes. Free Radic. Biol. Med. 1999, 26, 548-556. [CrossRef]

36. Roehm, N.W.; Rodgers, G.H.; Hatfield, S.M.; Glasebrook, A.L. An improved colorimetric assay for cell proliferation and viability utilizing the tetrazolium salt XTT. J. Immunol. Methods 1991, 142, 257-265. [CrossRef]

Sample Availability: Samples of the Lippia citriodora essential oil is available from the authors.

(C) 2018 by the authors. Licensee MDPI, Basel, Switzerland. This article is an open access article distributed under the terms and conditions of the Creative Commons Attribution (CC BY) license (http:/ / creativecommons.org/licenses/by/4.0/). 